\title{
PENGARUH PEMBERIAN GIBERELIN DAN AIR KELAPA TERHADAP PERKECAMBAHAN BIJI ANGGREK BULAN (Phalaenopsis sp.)
}

\author{
The Influence of Giberelin Addition and Coconut Water Against \\ Germination of Phalaenopsis sp. Seeds
}

\author{
Lilik Hidayatul Mukminin ${ }^{1}$, Putri Moortiyani Al Asna $^{1}{ }^{1}$, Frida Kunti Setiowati ${ }^{1}$ \\ ${ }^{1}$ Jurusan Biologi, FMIPA, Universitas Negeri Malang \\ ayatulmukminin@gmail.com
}

\begin{abstract}
Phalaenopsis sp. also known as "anggrek bulan" including of the Orchidaceae that having high economic value. Cultivation of orchidaceous plants so far constrained in orchid's seeds which has a germination less than 1 percent. Capacity's of orchid's seeds to germinate is low caused by small seeds and it has no endosperm so the germination of orchids seeds needs to be supported by hormone growing appropriate. Gibberellin and coconut water known can serve in the germination of orchids seeds. The purpose of this research to know the influence of the giberelin (GA3) addition and coconut water to the germination of Phalaenopsis sp. orchids seeds. Stage research conducted is to do sterilization, then seeds orchids inoculated in the MS medium with concentration variation GA3 $1 \mathrm{ppm}, 2 \mathrm{ppm}, 3 \mathrm{ppm}$ and variation treatment concentration coconut water $10 \mathrm{ml}, 20 \mathrm{ml}$, and $25 \mathrm{ml}$ and the combination between that treatment then observed in day $21^{\text {st }}$. The parameter that observed is the development of protocorm morphology and phase the development of protocorm analyzed in descriptively, the germination of Phalaenopsis sp. orchids seeds analyzed ANOVA and continued test tukey in the levels of trust $95 \%$ to see differences in between treatment. The development of protocorm in the three treatment show phase the development of protocorm different, namely the embryo to swell and tear testa, protocorm white with absorbing hair, protocorm yellowish white, and protocorm green round. The research results show that the Gibberellin (GA3) 3 ppm produce lowest germination level. There isn't real different germination level showed of Phalaenopsis sp. orchids seeds with the combination of Gibberellin (GA3) and coconut water with treatment MS media.
\end{abstract}

Keywords: Phalaenopsis sp., Gibberellin (GA3), coconut water, seed germination.

\begin{abstract}
Abstrak:Phalaenopsis sp. atau dikenal dengan nama dagang anggrek bulan termasuk famili Orchidaceae yang memiliki nilai ekonomis tinggi. Pembudidayaan tanaman anggrek selama ini terkendala pada biji anggrek yang memiliki daya kecambah kurang dari $1 \%$. Daya kecambah biji yang rendah disebabkan oleh ukuran biji yang kecil dan tidak mempunyai endosperm. Oleh karena itu, perkecambahan biji anggrek perlu didukung oleh hormon tumbuh yang sesuai. Giberelin dan air kelapa diketahui dapat berperan dalam perkecambahan biji. Tujuan dari penelitian ini untuk mengetahui pengaruh pemberian Giberelin (GA3) dan air kelapa terhadap perkecambahan biji anggrek bulan (Phalaenopsis sp). Tahapan penelitian yang dilakukan yaitu melakukan sterilisasi, kemudian biji Anggrek diinokulasikan dalam medium MS dengan perlakuan variasi konsentrasi GA3 1 ppm, 2 ppm, 3 ppm dan perlakuan variasi konsentrasi air kelapa $10 \mathrm{~mL}, 20 \mathrm{~mL}$, dan $25 \mathrm{~mL}$ beserta kombinasinya kemudian diamati pada hari ke-21. Parameter yang diamati berupa perkembangan morfologi protocorm dan fase perkembangan protocorm yang dianalisis secara deskriptif, sedangkan daya kecambah protocorm dianalisis ANOVA dan dilanjutkan uji Tukey pada tingkat kepercayaan 95\% untuk melihat adanya perbedaan antarperlakuan. Perkembangan protocorm pada 3 perlakuan memperlihatkan fase perkembangan protocorm yang berbeda, yaitu embrio membengkak dan merobek testa, protocorm putih dengan absorbing hair, protocorm putih kekuningan, dan protocorm hijau bulat. Hasil penelitian menunjukkan bahwa pemberian giberelin $\left(\mathrm{GA}_{3}\right) 3 \mathrm{ppm}$ menghasilkan daya kecambah paling rendah dan pemberian kombinasi antara GA3 dan air kelapa menunjukan daya kecambah yang tidak berbeda nyata dengan perlakuan MS.
\end{abstract}

Kata Kunci: Phalaenopsis sp., giberelin (GA3), air kelapa, perkecambahan biji. 


\section{PENDAHULUAN}

Phalaenopsis sp. atau dikenal dengan nama dagang anggrek bulan termasuk famili Orchidaceae yang memiliki nilai ekonomis tinggi. Pembudidayaan tanaman anggrek selama ini terkendala pada biji anggrek yang memiliki daya kecambah kurang dari 1\% (Gunawan, 2002). Daya kecambah biji yang rendah disebabkan oleh ukuran biji yang kecil dan tidak mempunyai endosperm. Oleh karena itu, perkecambah-an biji anggrek perlu didukung oleh hormon tumbuh yang sesuai.

Giberelin dan air kelapa diketahui dapat berperan dalam perkecambahan biji. Pemberian giberelin $\left(\mathrm{GA}_{3}\right) 0,15-0,2$ ppm diketahuidapatmeningkatkansecara nyata jumlah tunas, tinggi, jumlah daun, dan jumlah akar. Adapun pemberian air kelapa hanya meningkatkan jumlah akar, dan pemberian kombinasi antara GA3 dan air kelapa berpengaruh nyata terhadap jumlah akar dan jumlah tunas (Pandiangan dan Nainggolan, 2006). Kombinasi giberelin 2 ppm dan air kelapa $250 \mathrm{ml} / \mathrm{l}$ merupakan kombinasi terbaik pada perkecambahan biji anggrek bulan (Bey, et al. 2006). Tujuan dari penelitian ini untuk mengetahui pengaruh pemberian Giberelin (GA3) dan air kelapa terhadap perkecambahan biji anggrek bulan (Phalaenopsis sp).

\section{METODE PENELITIAN}

Penelitian dilakukan pada bulan Februari 2016 di Laboratorium Kultur Jaringan Tumbuhan Jurusan Biologi FMIPA Universitas Negeri Malang. Penelitian menggunakan Rancangan Acak Lengkap, pola faktorial $4 \times 4$. Faktor pertama berupa giberelin (GA3) dengan 4 taraf perlakuan terdiri dari $0 \mathrm{ppm}, 1 \mathrm{ppm}$, 2 ppm dan 3 ppm. Faktor kedua berupa air kelapa dengan 4 taraf perlakuan terdiri dari $0 \mathrm{ml} / \mathrm{l}, 150 \mathrm{ml} / \mathrm{l}, 200 \mathrm{ml} / \mathrm{l}$ dan $250 \mathrm{ml} / \mathrm{l}$. Setiap perlakuan terdiri dari 3 ulangan sehingga diperoleh 48 unit percoban.

Tahapan penelitian yang dilakukan yaitu melakukan sterilisasi, kemudian biji anggrek diinokulasikan dalam medium MS dengan perlakuan variasi konsentrasi GA3 1 ppm, 2 ppm, 3 ppm dan perlakuan variasi konsentrasi air kelapa $10 \mathrm{~mL}, 20 \mathrm{~mL}$, dan $25 \mathrm{~mL}$ beserta kombinasinya kemudian diamati pada hari ke-21. Parameter yang diamati berupa perkembangan morfologi protocorm dan fase perkembangan protocorm yang dianalisis secara deskriptif, sedangkan daya kecambah protocorm dianalisis ANOVA dan dilanjutkan uji Tukey pada tingkat kepercayaan 95\% untuk melihat adanya perbedaan antarperlakuan.

\section{HASIL DAN PEMBAHASAN}

Berdasarkan hasil pengamatan yang diperoleh tentang pengaruh penambahan Giberelin $\left(\mathrm{GA}_{3}\right)$ dan air kelapa beserta interaksinya terhadap perkecambahan Anggrek Bulan (Phaleonopsis sp.) diperoleh hasil yang beragam pada setiap perkecambahan biji hingga menjadi protocorm. Hasil penelitian menunjukkan bahwa pemberian giberelin $\left(\mathrm{GA}_{3}\right) 3 \mathrm{ppm}$ menghasilkan daya kecambah paling rendah, sedangkan pemberian kombinasi antara $\mathrm{GA}_{3}$ dan air kelapa menunjukan daya kecambah yang tidak berbeda nyata dengan perlakuan MS tanpa penambahan giberelin dan air kelapa. Daya kecambah biji Anggrek Phalaenopsis sp. disajikan pada Tabel 1. 
Tabel 1. Daya Kecambah Biji Anggrek Phalaenopsis sp. pada Minggu ke-3 dengan Variasi Konsentrasi GA3 dan Air Kelapa

\begin{tabular}{ccccc}
\hline Giberelin & \multicolumn{4}{c}{ Air Kelapa $(\mathrm{mL} / \mathrm{L})$} \\
\cline { 2 - 5 }$(\mathrm{mg} / \mathrm{L})$ & 0 & 100 & 200 & 250 \\
\hline 0 & $98,5^{\mathrm{a}}$ & $73,5^{\mathrm{b}}$ & $96,5^{\mathrm{a}}$ & $100^{\mathrm{a}}$ \\
1 & $98,5^{\mathrm{a}}$ & $99^{\mathrm{a}}$ & $94,5^{\mathrm{a}}$ & $99^{\mathrm{a}}$ \\
2 & $69,95^{\mathrm{b}}$ & $94,5^{\mathrm{a}}$ & $98^{\mathrm{a}}$ & $100^{\mathrm{a}}$ \\
3 & $13,64^{\mathrm{d}}$ & $75^{\mathrm{b}}$ & $97,5^{\mathrm{a}}$ & $56,2^{\mathrm{c}}$ \\
\hline
\end{tabular}

Keterangan: angka yang diikuti dengan huruf yang sama pada kolom yang sama menunjukkan tidak beda nyata pada taraf kepercayaan $95 \%$.

Semua perlakuan penambahan giberelin dan air kelapa dengan berbagai konsentrasi beserta interaksinya dihasilkan perkecambah-an dan perkembangan protocorm like bodies (plb) yang berbeda. Perkecambahan dan per-kembangan kalus pada perlakuan penambahan air kelapa dengan berbagai volume pada Media Murashige and Skoog (MS) tidak menghasilkan perkecambahan biji anggrek bulan (Phalaeonopsis sp.) yang efektif dan signifikan. Penambahan air kelapa pada media perkecambahan anggrek seharusnya dapat menstimulasi perkecambahan dan pertumbuhan. George dan Sherrington (1984) menyatakan bahwa penggunaan zat pengatur tumbuh (ZPT) dalam kultur in vitro pada batas tertentu mampu merangsang pertumbuhan namun dapat bersifat sebagai inhibitor apabila digunakan melebihi konsentrasi optimum. Adapun pemberian air kelapa menunjukkan daya perkecambahan dan perkembangan morfologi yang lebih lambat daripada perlakuan yang lain. Hal ini kurang sesuai dengan Bey et al., (2006) yang mengatakan bahwa air kelapa muda merupakan suatu cairan yang mengandung unsur hara dan ZPT sehingga dapat menstimulasi perkecambahan dan pertumbuhan.

Perkembangan biji pada masingmasing perlakuan berbeda. Awal perkembangan, bentuk embrio berada di dalam testa dengan ukuran yang tidak terlalu besar. Beberapa hari kemudian, biji mengalami pembengkakan dan tampak adanya gegaris testa. Biji terus mengalami pembengkakan dan testa hanya akan tersisa sedikit yang melekat pada ujung protocorm. Protocorm selanjutnya akan berubah kekuningan kemudian akan semakin hijau dan membulat yang akan disusul dengan munculnya SAM (Shoot Apical Meristem).

Morfologi biji anggrek Phalaenopsis sp. diamati berdasarkan pada perkembangan protocorm yang terdiri dari 6 fase (Dwiyani et al., 2012). Perkembangan morfologi Protocorm anggrek Phalaenopsis sp. pada minggu ke-3 dengan variasi konsentrasi $\mathrm{GA}_{3}$ dan air kelapa seperti tersaji pada Tabel 2.

Tabel 2. Perkembangan Morfologi Protocorm Anggrek Phalaenopsis sp. pada Minggu ke-3 dengan Variasi Konsentrasi GA3 dan Air Kelapa

\begin{tabular}{|c|c|c|c|c|c|c|c|c|c|c|c|c|c|c|c|c|}
\hline \multirow{3}{*}{ Ciri Morfologi } & \multicolumn{16}{|c|}{ Perlakuan } \\
\hline & G0 & G0 & G0 & G0 & G1 & G1 & G1 & G1 & G2 & G2 & G2 & G2 & G3 & G3 & G3 & G3 \\
\hline & A0 & A1 & A2 & A3 & A0 & A1 & A2 & A3 & A0 & A1 & A2 & A3 & A0 & A1 & A2 & A3 \\
\hline Biji membengkak & - & - & $\sqrt{ }$ & $\sqrt{ }$ & $\sqrt{ }$ & $\sqrt{ }$ & $\sqrt{ }$ & - & - & - & - & - & $\sqrt{ }$ & $\sqrt{ }$ & $\sqrt{ }$ & $\sqrt{ }$ \\
\hline $\begin{array}{l}\text { Embrio keluar dari } \\
\text { testa }\end{array}$ & - & $\sqrt{ }$ & $\sqrt{ }$ & $\sqrt{ }$ & - & $\sqrt{ }$ & $\sqrt{ }$ & - & - & - & - & $\sqrt{ }$ & $\sqrt{ }$ & $\sqrt{ }$ & $\sqrt{ }$ & $\sqrt{ }$ \\
\hline
\end{tabular}




\begin{tabular}{|c|c|c|c|c|c|c|c|c|c|c|c|c|c|c|c|c|}
\hline \multirow{3}{*}{ Ciri Morfologi } & \multicolumn{16}{|c|}{ Perlakuan } \\
\hline & G0 & G0 & G0 & G0 & G1 & G1 & G1 & G1 & G2 & G2 & G2 & $\mathrm{G} 2$ & G3 & G3 & G3 & G3 \\
\hline & A0 & A1 & A2 & A3 & A0 & A1 & A2 & A3 & A0 & A1 & A2 & A3 & A0 & A1 & A2 & A3 \\
\hline $\begin{array}{l}\text { Protocorm } \\
\text { berwarna putih } \\
\text { tulang }\end{array}$ & $\sqrt{ }$ & $\sqrt{ }$ & $\sqrt{ }$ & $\sqrt{ }$ & - & $\sqrt{ }$ & $\sqrt{ }$ & - & $\sqrt{ }$ & $\sqrt{ }$ & $\sqrt{ }$ & $\sqrt{ }$ & - & $\sqrt{ }$ & $\sqrt{ }$ & $\sqrt{ }$ \\
\hline $\begin{array}{l}\text { Protocorm } \\
\text { membulat }\end{array}$ & $\sqrt{ }$ & $\sqrt{ }$ & $\sqrt{ }$ & $\sqrt{ }$ & $\sqrt{ }$ & $\sqrt{ }$ & $\sqrt{ }$ & $\sqrt{ }$ & $\sqrt{ }$ & $\sqrt{ }$ & $\sqrt{ }$ & $\sqrt{ }$ & $\sqrt{ }$ & - & $\sqrt{ }$ & $\sqrt{ }$ \\
\hline $\begin{array}{l}\text { Protocorm } \\
\text { berwarna } \\
\text { kekuningan }\end{array}$ & $\sqrt{ }$ & $\sqrt{ }$ & $\sqrt{ }$ & $\sqrt{ }$ & $\sqrt{ }$ & - & - & $\sqrt{ }$ & $\sqrt{ }$ & $\sqrt{ }$ & $\sqrt{ }$ & $\sqrt{ }$ & $\sqrt{ }$ & $\sqrt{ }$ & $\sqrt{ }$ & $\sqrt{ }$ \\
\hline Muncul AH & $\sqrt{ }$ & $\sqrt{ }$ & $\sqrt{ }$ & $\sqrt{ }$ & $\sqrt{ }$ & - & - & - & $\sqrt{ }$ & - & - & $\sqrt{ }$ & $\sqrt{ }$ & - & - & - \\
\hline AH tumbuh merata & $\sqrt{ }$ & $\sqrt{ }$ & $\sqrt{ }$ & $\sqrt{ }$ & $\sqrt{ }$ & - & - & - & $\sqrt{ }$ & - & - & $\sqrt{ }$ & - & - & - & - \\
\hline $\begin{array}{l}\text { Protocorm } \\
\text { berwarna hijau }\end{array}$ & $\sqrt{ }$ & $\sqrt{ }$ & $\sqrt{ }$ & $\sqrt{ }$ & $\sqrt{ }$ & $\sqrt{ }$ & $\sqrt{ }$ & $\sqrt{ }$ & $\sqrt{ }$ & $\sqrt{ }$ & $\sqrt{ }$ & $\sqrt{ }$ & $\sqrt{ }$ & - & $\sqrt{ }$ & $\sqrt{ }$ \\
\hline Muncul SAM & $\sqrt{ }$ & - & - & - & $\sqrt{ }$ & - & $\sqrt{ }$ & $\sqrt{ }$ & $\sqrt{ }$ & $\sqrt{ }$ & $\sqrt{ }$ & $\sqrt{ }$ & $\sqrt{ }$ & - & - & - \\
\hline
\end{tabular}

Keterangan: $\mathrm{AH}=$ Absorbing Hairs, SAM = Shoot Apical Meristem .

Dwiyani et al., (2012), menyatakan bahwa perkembangan morfologi biji anggrek Phalaenopsis sp. yang terdiri dari 6 fase dimulai dari biji yang belum berkecambah hingga protocorm dengan SAM (Shot
Apical Meristem). Tahap perkecambahan Anggrek Phalaenopsis sp. secara mikroskopik pada minggu ke-3 dengan variasi konsentrasi $\mathrm{GA}_{3}$ dan air kelapa tersaji pada Gambar 1.

Gambar 1. Hasil Pengamatan Mikroskopis Fase Perkecambahan Biji Anggrek Phalaenopsis sp. Ket: (1) Biji belum berkecambah, (2) Biji membengkak, (3) Biji keluar dari testa, (4) Protocorm mulai berkembang dan berwarna putih kekuningan, (5) Protocorm munculnya membulat dan munculnya Absorbing Hair (AH) ( ), (6) Protocorm berwarna hijau dan muncul Shoot Apical Meristem (SAM) ( ).

(Sumber: Dokumentasi pribadi, 2016)

Perkecambahan adalah proses pertumbuh-an embrio dan komponen biji yang mempunyai kemampuan untuk tumbuh secara normal menjadi tanaman baru. Jaringan yang mengalami hidrasi akan memicu aktivasi giberelin yang ada di dalam jaringan sehingga jaringan mengeluarkan enzim hidrolitik. Aktivasi giberelin diikuti dengan aktifnya auksin dan sitokinin. Keberadaan auksin pada sel menyebabkan peningkatan permeabilitas sel terhadap air sehingga tekanan dinding sel menurun. Hal tersebut menyebabkan dinding sel melunak yang ditandai 
dengan pecahnya kulit biji sehingga air dapat masuk ke dalam sel yang menyebabkan bertambahnya volume sel (Hopkins dan Huner, 2008).

Air kelapa berpengaruh terhadap perkecambahan biji anggrek karena mengandung sitokinin (George dan Sherington, 1984) yaitu zat pengatur tumbuh utama yang terdapat dalam air kelapa adalah sitokinin. Penelitian lebih lanjut yang dilakukan oleh Dwidjoseputro (1989) menunjukkan bahwa selain mengandung kalori, protein, dan mineral, air kelapa muda mengandung sitokinin yaitu zat pengatur tumbuh yang mempercepat pembelahan sel. Hal ini didukung oleh pendapat Widiastoety (2008) yang menyatakan bahwa air kelapa mengandung zat atau bahan-bahan seperti karbohidrat, vitamin, mineral, protein serta zat tumbuh auksin, sitokinin dan giberelin yang berfungsi sebagai pemicu terjadinya proliferasi jaringan, metabolisme dan respirasi sel. Air kelapa muda juga merupakan suatu bahan alami yang di dalamnya terkandung hormon seperti sitokinin 5,8 mg/l yang dapat merangsang pertumbuhan tunas dan mengaktifkan kegiatan jaringan atau sel hidup, hormon auksin 0,07 mg/L dan sedikit giberelin serta senyawa lain yang dapat menstimulasi perkecambahan dan pertumbuhan (Morel 1974, dalam Bey et al. 2006).

\section{SIMPULAN}

Hasil penelitian menunjukkan bahwa pemberian giberelin $\left(\mathrm{GA}_{3}\right) 3 \mathrm{ppm}$ menghasilkan daya kecambah paling rendah dan pemberian kombinasi antara $\mathrm{GA}_{3}$ dan air kelapa menunjukan daya kecambah yang tidak berbeda nyata dengan perlakuan MS.

\section{DAFTAR PUSTAKA}

Bey, Y., Syafii, W. dan Sutrisna. 2006. Pengaruh Pemberian Giberelin $\left(\mathrm{GA}_{3}\right)$ dan Air Kelapa terhadap Perkecambahan Bahan Biji Anggrek Bulan (Phalaenopsis Amabilis Bl) secara In Vitro. Jurnal Biogenesis, 2(2): 41-46.

Dwidjoseputro, D. 1989. Pengantar Fisiologi Tumbuhan. Jakarta: Gramedia.

Dwiyani, R., Purwantoro, A., Indrianto, A., dan Semiarti, E. 2012. Konservasi Anggrek Alam Indonesia Vanda tricolor Lindl. varietas suavis Melalui Kultur Embrio Secara InVitro. Jurnal Bumi Lestari. 12(1):9398.

George, E. F. dan Sherington, P. D. 1984. Plant Propagation by Tissue Culture. Exegetis Limited: England.

Hopkins, W.G. dan Huner, N.P.A. 2008. Introduction of Plant Physiology: $4^{\text {th }}$ edition. USA: John Wiley \& Sons, Inc.

Pandiangan, S. dan Nainggolan, T. 2006. Pengaruh pemberian giberelin (GA3) dan air kelapa terhadap pertumbuhan planlet tanaman anggrek (Dendrobium sp.) secara In Vitro. Jurnal Komunikasi Penelitian, 18(2): $30-33$.

Widiastoety D, 2008. Pengaruh Thiamin terhadap Pertumbuhan Anggrek Oncidium secara in Vitro. Balai Penelitian Tanaman Hias: Cianjur. 